Formatif: Jurnal Ilmiah Pendidikan MIPA

Vol. 8, No. 1, April 2018, pp. 43-50

p-ISSN: 2088-351X

e-ISSN: 2502-5457

DOI: http://dx.doi.org/10.30998/formatif.v8i1.2319

\title{
Improving Mathematics Learning Outcomes Through Cooperative Learning Model Type NHT In Grade VIII A Students MTs Muhammadiyah
}

\author{
Meningkatkan Hasil Belajar Matematika Melalui Model Pembelajaran Kooperatif \\ Tipe NHT Pada Siswa Kelas VIII A MTS Muhammadiyah Kota Sorong
}

\author{
Muhamad Ruslan Layn \\ Universitas Muhammadiyah Sorong
}

\begin{abstract}
Received: March 1, $2018 \quad \begin{aligned} & \text { Abstract } \\ & \text { This research is a Classroom Action Research (CAR), which aims to improve }\end{aligned}$ Revised: March 19,2018 the learning outcomes of mathematics through NHT type cooperative Accepted: March 25, 2018 learning model in students of class VIII A MTs. Muhammadiyah conducted collaboratively between researchers and teachers of mathematics studies. In the implementation of this research, it is done by giving group worksheet and observation sheet of student activity using NHT type cooperative learning model after giving explanation about Pythagoras Theorem material as much as two cycles that are cycle I and II. After being given group work sheets then conducted the assessment includes assessment of test results of cycle I and cycle II and group worksheet to students that is by applying learning model of cooperative learning type NHT. The subjects of this study were students of class VIII A which amounted to 20 students consisting of 15 male students and 5 female students. Techniques of collecting data in research is this observation and test. The data obtained were then analyzed. The results of the study showed that the implementation using NHT type cooperative learning model on Pythagoras Theorem material. the ability of students in solving problems on the material above has increased. With the increase of the average value of students in the first cycle was 43.45 and increased in cycle II 83.90. Improvement of student learning outcomes to mathematics learning using NHT type cooperative learning is good. This is indicated by the average value of group learning outcomes in cycle I 60.00 or being in the medium category and the average score of the learning outcomes of the group in cycle I 82.50 or in the high category. This shows the result of increased mathematics learning after conducting cooperative learning model of NHT type.
\end{abstract}

Keywords: Model Pembelajaran Kopertif Tipe NHT, Hasil Belajar, Belajar

(*) Corresponding Author: E-mail: ruslanlayn56@gmail.com

How to Cite: Layn, M. R. (2018). Improving mathematics learning outcomes through cooperative learning model type NHT in grade VIII A students MTs Muhammadiyah. Formatif: Jurnal Ilmiah Pendidikan MIPA, 8 (1): 43-. http://dx.doi.org/10.30998/formatif.v8i1.2319

\section{PENDAHULUAN}

Matematika merupakan salah satu mata pelajaran yang diterapkan di berbagai tingkat pendidikan, mulai dari SD, SMP, SMA, bahkan sampai perguruan tinggi. Kebanyakan siswa menganggap matematika adalah mata pelajaran yang sulit dibandingkan mata pelajaran lainnya, hal ini disebabkan karena materinya terdiri dari konsep-konsep yang terstruktur rapi, seperti rumus-rumus. Siswa selalu menghafalkan 
Formatif: Jurnal Ilmiah Pendidikan MIPA

Vol. 8, No. 1, April 2018, pp. 43-50

p-ISSN: 2088-351X

e-ISSN: $2502-5457$

DOI: http://dx.doi.org/10.30998/formatif.v8i1.2319

rumus-rumus tanpa dipahami dari mana asal usulnya. Padahal pembelajaran matematika mampu melatih manusia untuk belajar berpikir secara praktis, menggunakan logika, bersikap kritis dan kreatif serta sistematis dalam setiap tindakannya.

Keberhasilan proses pembelajaran pada pelajaran metematika dapat diukur dari keberhasilan siswa yang mengikuti tersebut. Keberhasilan itu dapat dilihat dari tingkat pemahaman, penguasaan materi serta prestasi belajar siswa. Semakin tinggi pemahaman dan penguasaan materi serta prestasi belajar maka semakin tinggi pula tingkat keberhasilan pembelajaran. Namun, dalam kenyataannya dapat dilihat bahwa hasil belajar matematika yang dicapai siswa masih rendah. Hal ini dikarenakan, metode, model dan strategi yang digunakan oleh guru masih kurang bervariatif sehigga kemampuan siswa dalam proses pembelajaran masih cenderung masih di bawah KKM. selain dari permasalahan di atas, Kusnandar (2009) mengatakan pada pembelajaran matematika juga ditemukan keragaman masalah sebagai berikut, (1) Keaktifan siswa dalam mengikuti pembelajaran masih belum tampak, (2) Para siswa jarang mengajukan pertanyaan, walaupun guru sering meminta agar siswa bertanya jika ada hal-hal yang belum jelas, atau kurang paham, (3) Keaktifan dalam mengerjakan soal-soal latihan pada proses pembelajaran juga masih kurang,(4) Kurangnya keberanian siswa untuk mengerjakan soal di depan kelas.

Menganalisis permasalahan tersebut, proses pembelajaran siswa perlu di modifikasi ke dalam model pembelajaran kooperatif tipe NHT (Numbered Heads Together), karena dengan model ini siswa memiliki peran yang sangat dominan dalam proses pembelajaran, terjalinnya kerja sama dalam kelompok. Model pembelajaran NHT pada dasarnya adalah variasi diskusi kelompok yang berkarateristik guru hanya menunjuk siswa yang mewakili kelompoknya tanpa sepengatahuan kelompok tersebut. Oleh karenanya peran siswa dalam pembelajaran di kelas dapat berjalan secara optimal. Selain itu model pembelajaran kooperatif tipe NHT mampu memotivasi dan menarik aktivitas belajar siswa di kelas untuk berusaha memahami setiap penugasan yang diberikan dan bertanggung jawab atas tugasnya masing-masing. Dengan adanya pemilihan model tersebut, diharapkan pembelajaran yang diajarkan dapat bermakna dan mampu di aplikasi dalam kehidupan sehari-hari. Prihatini (2017), Khoiri et.al. (2017) menyatakan bahwa pemilihan suatu metode pembelajaran mampu meningkatkan penguasaan konsep siswa dalam pembelajaran di kelas, selain dari konsep siswa juga mampu meningkatkan prestasi belajar dan menumbuhkan minat siswa dalam mengikuti pembelajaran.

Di sisi lain untuk mengatasi permasalahan terjadi, salah satu usaha yang harus dilakukan guru matematika adalah mengoptimalkan keberadaan siswa sebagai obyek dan sekaligus subjek pembelajaran. Maksud objek pembelajaran, karena siswalah yang menerima materi pembelajaran, sedangkan subjek pembelajaran karena yang aktif dalam kegiatan pembelajaran tidak selalu guru. Artinya siswa pun perlu diaktifkan dalam kegiatan pembelajaran. Salah satu cara yang dapat digunakan guru untuk mengaktifkan siswa adalah dengan menggunakan pembelajaran kooperatif (cooperative learning).

Kahar (2017) mengemukakan bahwa Pembelajaran kooperatif dapat meningkatkan kemampuan siswa dalam bekerja secara berkolaborasi untuk mencapai tujuan pembelajaran. Selain itu, pembelajaran dengan model tersebut juga memberikan sumbangsih terhadap peningkatan partisipasi siswa, aktivitas siswa, serta memberikan kesempatan pada siswa untuk berinteraksi dan belajar bersama-sama siswa yang berbeda latar belakangnya. Di sisi lain Pembelajaran kooperatif juga dirancang untuk mempengaruhi pola interaksi siswa dalam kelas sebagai bentuk peningkatan kemampuan siswa dalam memahami materi yang diajarkan, sehingga pada hakikatnya siswa mampu mengikuti tahap-tahap yang diterapkan pada model pembelajaran yang diterapkan. 


\section{Formatif: Jurnal Ilmiah Pendidikan MIPA}

Vol. 8, No. 1, April 2018, pp. 43-50

p-ISSN: 2088-351X

e-ISSN: 2502-5457

DOI: http://dx.doi.org/10.30998/formatif.v8i1.2319

NHT (Numbered Heads Together) merupakan tipe pembelajaran kooperatif yang dirancang untuk memengaruhi pola interaksi siswa dan sebagai alternatif terhadap struktur kelas tradisional. Pada dasarnya NHT merupakan varian dari diskusi kelompok. Teknis pelaksanaannya hampir sama dengan diskusi kelompok. Pertama guru meminta siswa untuk duduk berkelompok. masing-masing anggota diberi nomor. Setelah selesai, guru memanggil nomor untuk mempresentasikan hasil diskusinya. guru tidak memberitahukan nomor berapa yang akan mempresentasikan selanjutnya. begitu seterusnya hingga semua nomor terpanggil. Pemanggilan secara acak ini akan memastikan semua siswa benar-benar terlibat dalam diskusi tersebut (Huda, 2011).

\section{METODE}

Jenis penelitian yang digunakan adalah penelitian tindakan kelas (classroom action reseach) dengan dua siklus, setiap siklus terdiri atas 4 tahap, yaitu perencanaan, tindakan, observasi, dan refleksi. Desain penelitian tindakan kelas yang digunakan dalam penelitian ini adalah desain penelitian yang dikembangkan oleh Kemmis dan Mc. Taggart, 1983.

Subjek yang akan diambil dalam penelitian ini yaitu siswa kelas VIII A dengan jumlah 20 siswa yang terdiri dari 15 siswa laki-laki dan 5 siswa perempuan, yang menjadi Instrumen data dalam penelitian ini adalah sebagai beriku, (1) Menyiapkan Rencana Pelaksanaan Pembelajaran ( RPP ), (2) Lembar Kerja Kelompok ( LKK ), (3) Alat Evaluasi (Tes Hasil Belajar). Data yang dikumpulkan akan dianalisis secara kuantitatif dan kualitatif. Data hasil observasi dianalisis secara kualitatif, sedangkan data hasil tes (evaluasi) dianalisis secara kuantitatif dengan menggunakan teknik analisis deskriptif, yang terdiri atas: nilai rata-rata (mean), nilai maksimum dan nilai minimum siswa yang diperoleh pada setiap siklus dengan menggunakan program SPSS 16. Hasil tes hasil belajar yang diperoleh siswa harus memenuhi standar kriteria ketuntasan minimal (KKM) sebesar 65 .

\section{HASIL DAN PEMBAHASAN}

\section{Hasil}

\section{a. Hasil Tes Siklus I}

Hasil analisis statistik deskriptif pada nilai kemampuan siswa dalam hal ini dilihat dari hasil belajar matematika pada kelas VIIIA MTs. Muhammadiyah Kota Sorong terhadap pokok bahasan Dalil Pytagoras yang diajarkan pada Siklus I, terlihat dalam tabel 1.

Tabel. 1 Statistik Nilai Hasil Belajar Matematika Pada Kelas VIIIA MTs. Muhammadiyah Kota Sorong pada Siklus I

\begin{tabular}{cc}
\hline Statistik & Nilai Statistik \\
\hline Subjek & 20 \\
Nilai ideal & 100 \\
Nilai tertinggi & 90 \\
Nilai terendah & 10 \\
Rentang nilai & 80 \\
Nilai rata-rata & 43,45 \\
Standar Deviasi & 22,25 \\
\hline
\end{tabular}




\section{Formatif: Jurnal Ilmiah Pendidikan MIPA}

Vol. 8, No. 1, April 2018, pp. 43-50

p-ISSN: 2088-351X

e-ISSN: 2502-5457

DOI: http://dx.doi.org/10.30998/formatif.v8i1.2319

Dari tabel 1 terlihat bahwa skor rata-rata hasil belajar matematika Pada Kelas VIIIA MTs. Muhammadiyah Kota Sorong terhadap pokok bahasan teorema Pythagoras pada siklus I adalah 43,45 dari nilai ideal maksimum yang mungkin dicapai yaitu 100 dengan standar deviasinya 22,51. Sedangkan secara individual, nilai yang dicapai siswa pada siklus I tersebut dari nilai terendah 10 dari nilai terendah yang mungkin dicapai 0 sampai dengan nilai tertinggi 90 dari nilai tertinggi yang mungkin dicapai 100 dengan rentang skor 80. Hal ini menunjukan bahwa hasil belajar matematika siswa cukup bervariasi dari nilai yang terendah 10 sampai tertinggi 90. Jika nilai hasil belajar siswa di atas dikelompokan kedalam lima kategori, maka diperoleh distribusi frekuensi dan persentase seperti disajikan sebagai berikut,

Tabel 2. Distribusi Frekuensi Nilai Tes Hasil Belajar Individu Pokok Bahasan Teorema Pythagoras dengan menggunakan model pembelajaran kooperatif tipe NHT pada Siklus I

\begin{tabular}{cccc}
\hline Kategori & Frekuensi & Persentase & Keterangan \\
Sangat rendah & 8 & $40 \%$ & Di bawah KKM \\
Rendah & 7 & $35 \%$ & Di bawah KKM \\
Sedang & 0 & $0 \%$ & Di bawah KKM \\
Tinggi & 4 & $20 \%$ & Di atas KKM \\
Sangat tinggi & 1 & $5 \%$ & Di atas KKM
\end{tabular}

Ketuntasan Klasikal $=5: 20 \times 100 \%=25 \%$

Setelah digunakan kategorisasi pada tabel 2 terlihat bahwa dari 20 siswa yang dijadikan subjek penelitian, maka pada siklus I yaitu Perolehan nilai pemahaman konsep teorema Pythagoras pada Siklus I yaitu siswa yang mendapat nilai di bawah KKM sebanyak 15 siswa atau 75\% dan siswa yang mendapat nilai atas KKM sebanyak 5 siswa atau $25 \%$ berdasarkan ketuntasan klasikal sebesar 65 .

Jika nilai rata-rata hasil belajar tes individu pada Siklus I sebesar 43,45 dengan standar deviasi 22,55. Jika dikonversi ke dalam tabel kategorisasi, ternyata berada dalam kategori rendah. Hal ini menunjukan bahwa kemampuan siswa kelas VIIIA MTs. Muhammadiyah Kota Sorong setelah pemberian model pembelajaran kooperatif tipe NHT pada siklus 1 berada dalam kategori rendah.

\section{b. Hasil Tes Siklus II}

Hasil analisis statistik deskriptif menunjukan bahwa rata-rata skor yang dicapai oleh pada Kelas VIIIA MTs. Muhammadiyah Kota Sorong terhadap pokok bahasan Teorema Pythagoras yang diajarkan pada Siklus II dapat dilihat dalam tabel 3.

Tabel. 3 Statistik Nilai Hasil Belajar Matematika pada Kelas VIIIA MTs. Muhammadiyah Kota Sorong pada Siklus II

\begin{tabular}{cc}
\hline Statistik & Nilai Statistik \\
\hline Subjek & 20 \\
Nilai ideal & 100 \\
Nilai tertinggi & 100 \\
Nilai terendah & 62 \\
Rentang nilai & 38 \\
Nilai rata-rata & 84 \\
\hline
\end{tabular}


Formatif: Jurnal Ilmiah Pendidikan MIPA

Vol. 8, No. 1, April 2018, pp. 43-50

p-ISSN: 2088-351X

e-ISSN: 2502-5457

DOI: http://dx.doi.org/10.30998/formatif.v8i1.2319

Standar Deviasi 13,06

Rata-rata nilai hasil belajar matematika pada Kelas VIIIA MTs. Muhammadiyah Kota Sorong terhadap pokok bahasan teorema Pythagoras pada Siklus II adalah 83,90 dengan standar deviasi 13,06. Sedangkan secara individual, nilai yang dicapai siswa tersebar dari nilai terendah 62 dengan rentang nilai 38. Ini menunjukan bahwa hasil belajar matematika siswa setelah Siklus II cukup bervariasi dari nilai yang rendah 62 sampai dengan nilai yang sangat tinggi 100 .

Jika nilai hasil belajar siswa di atas menunjukan ke dalam lima kategori, maka diperoleh distribusi frekuensi dan persentase seperti yang disajikan pada tabel 4 .

Tabel 4. Distribusi frekuensi dan Persentase Nilai Tes Individu Pokok Bahasan Teorema Pythagoras dengan Menggunakan Model Pembelajaran Kooperatif Tipe NHT Pada Siklus

II

$\begin{array}{lllll}\begin{array}{l}\text { Interval } \\ 5-34\end{array} & \begin{array}{l}\text { Kategori } \\ \text { Sangat rendah }\end{array} & \begin{array}{l}\text { Frekuensi } \\ 0\end{array} & \begin{array}{l}\text { Persentase } \\ 0 \%\end{array} & \begin{array}{l}\text { Keterangan } \\ \text { Di bawah KKM }\end{array} \\ 5-54 & \text { Rendah } & 0 & 0 \% & \text { Di bawah KKM } \\ 5-64 & \text { Sedang } & 2 & 10 \% & \text { Di bawah KKM } \\ 5-84 & \text { Tinggi } & 8 & 40 \% & \text { Di atas KKM } \\ 5-100 & \text { Sangat tinggi } & 10 & 50 \% & \text { Di atas KKM }\end{array}$

Ketuntaan Klasikal $=18: 20 \times 100 \%=90 \%$

Setelah digunakan kategorisasi pada tabel 4 terlihat bahwa dari 20 orang siswa yang dijadikan subjek penelitian, maka berdasarkan refleksi dari pelaksanaan siklus I, pada siklus yang II ini siswa sudah lebih antusias dalam belajar, bekerjasama dalam kelompok dengan baik, dan sebagian besar siswa sudah lebih aktif dalam mengikuti pelajaran. Ini terbukti pada siklus kedua ini terjadi peningkatan nilai rata-rata siswa mengalami peningkatan dari 43,45 pada siklus I, dan meningkat lagi pada siklus II sebesar 84. Berdasarkan tabel 4 di atas, Perolehan nilai pemahaman konsep teorema Pythagoras pada Siklus II yaitu siswa yang mendapat nilai di bawah KKM sebanyak 2 siswa atau 10\% dan siswa yang mendapat nilai di atas KKM sebanyak 18 siswa atau 90\% siswa memperoleh nilai di atas KKM, oleh karenanya, proses pembelajaran pada siklus ini siswa mampu memahami materi yang diajarkan oleh guru.

Jika nilai rata-rata hasil belajar tes Siklus II sebesar 84 dengan standar deviasi 13,06. Maka berdasarkan Tabel 4 hasil belajar matematika pada kelas VIIIA MTs Muhammadiyah Kota Sorong pada siklus II termasuk dalam karegori tinggi. Dari perbandingan nilai rata-rata hasil belajar matematika pada kelas VIIIA MTs Muhammadiyah Kota Sorong setelah dilaksanakan pembelajaran selama dua Siklus dapat dilihat pada tabel 5 .

Tabel 5 Nilai Rata-Rata Hasil Belajar Matematika Pada kelas VIIIA MTs. Muhammadiyah Kota Sorong untuk Siklus I dan Siklus II

\begin{tabular}{cccc}
\hline No & Aspek & Siklus I & Siklus II \\
1 & Nilai tertinggi & 90 & 100 \\
\hline
\end{tabular}


Formatif: Jurnal Ilmiah Pendidikan MIPA

Vol. 8, No. 1, April 2018, pp. 43-50

p-ISSN: 2088-351X

e-ISSN: 2502-5457

DOI: http://dx.doi.org/10.30998/formatif.v8i1.2319

\begin{tabular}{lccc}
\hline & & \\
\hline 2 & Nilai terendah & 10 & 62 \\
3 & Nilai rata-rata & 43,45 & 84 \\
4 & Siswatuntas belajar & 5 & 18 \\
5 & Siswatidak tuntas belajar & 15 & 2 \\
6 & Ketuntasan klasikal & $25 \%$ & $90 \%$ \\
\hline
\end{tabular}

\section{Pembahasan}

Berdasarkan analisis data di atas maka dapat diketahui bahwa model kooperatif tipe NHT dapat meningkatkan hasil belajar pada siswa kelas VIII A MTs. Muhammadiyah Kota Sorong. Hal ini didukung dengan pendapat Baskoro, dkk (2013) yang mengemukakan bahwa NHT menggunakan nomor untuk tiap kelompok, dan menggunakan kuis-kuis dan sistem skor kemajuan individu, dimana para siswa berlomba sebagai wakil tim mereka dengan anggota lain yang kinerja akademik sebelumnya setara seperti mereka.

Berdasarkan hasil analisis data dapat ditemukan peningkatan pemahaman konsep teorema Pythagoras dan peningkatan aktivitas siswa. Hal ini, menandakan bahwa penerapan model kooperatif tipe NHT dalam pembelajaran matematika pokok bahasan teorema Pythagoras dapat meningkatkan aktivitas belajar siswa dan membuat pembelajaran matematika pokok bahasan Teorema Pythagoras menjadi lebih bermakna, karena pembelajaran lebih menyenangkan, memudahkan siswa untuk memahami materi yang ada dengan bertukar informasi bersama teman-teman, meningkatkan rasa kerja sama dan tanggung jawab dalam satu kelompok untuk meraih tujuan yang sama yaitu memahami materi bersama-sama dan berkompetisi secara sehat guna mencapai tujuan. Hal ini sejalan dengan Kahar, (2017), Florentina \& Leonard, (2017). menyatakan bahwa kemampuan siswa memahami materi pembelajaran sangat berperan dalam tingkat pemahaman siswa dalam mengerjakan soal yang diberikan. Selain itu, dengan penggunaan variasi model pembelajaran di kelas dapat lebih meningkatkan kemampuan berpikir matematis siswa akan materi yang diajarkan. Dengan demikian dapat diketahui bahwa, salah satu upaya untuk meningkatkan pemahaman konsep teoema Pythagoras mata pelajaran matematika pada siswa kelas VIII A MTs. Muhammadiyah Kota Sorong yaitu dengan menerapkan model kooperatif tipe NHT. Penerapan model kooperatif tipe NHT dapat menjadikan pembelajaran matematika pokok bahasan teorema Pythagoras menjadi lebih menyenangkan sehingga pemahaman siswa meningkat. Jadi, pembelajaran dengan penerapan model kooperatif tipe NHT dapat meningkatkan hasil belajar matematika pada materi Teorema Pythagoras bagi siswa kelas VIII A MTs. Muhammadiyah Kota Sorong.

\section{PENUTUP}

Berdasarkan hasil penelitian yang telah dilaksanakan dalam dua siklus yang tiap siklusnya terdiri dari empat pertemuan, ternyata rumusan masalah yang dirumuskan telah terbukti kebenarannya. Pembelajaran dengan penerapan model kooperatif tipe NHT dapat meningkatkan pemahaman konsep teorema Pythagoras pada siswa kelas VIII A Mts. Muhammadiyah Kota Sorong. Hal ini, terbukti pada siklus I nilai rata-rata hasil belajar siswa sebesar 43,45 dengan persentase ketuntasan klasikal sebesar 25\%, dan siklus II nilai rata-rata hasil belajar siswa sebesar 84 dengan persentase ketuntasan klasikal sebesar 90\%.Pembelajaran dengan penerapan model kooperatif tipe dan NHT dapat dilaksanakan untuk meningkatkan keaktifan dan kerjasama siswa dalam diskusi kelompok. Hal ini, 


\section{Formatif: Jurnal Ilmiah Pendidikan MIPA}

Vol. 8, No. 1, April 2018, pp. 43-50

p-ISSN: 2088-351X

e-ISSN: 2502-5457

DOI: http://dx.doi.org/10.30998/formatif.v8i1.2319

dibuktikan berdasarkan nilai hasil diskusi kelompok atau turnamen siswa, pada siklus I nilai rata-rata hasil belajar kelompok (turnamen) siswa sebesar 60,00 dan pada siklus II meningkat menjadi 82,5. Pembelajaran dengan penerapan model kooperatif tipe NHT juga dapat dilaksanakan untuk meningkatkan kualitas pembelajaran matematika di kelas VIII sehingga dapat meningkatakan hasil belajar matematika pada materi teorema Pythagoras.

\section{DAFTAR PUSTAKA}

Baskoro, F., Saputro, S., \& Hastuti, B. (2013). Upaya peningkatan aktivitas dan prestasi belajar dengan model pembelajaran NHT (numbered head together) dilengkapi LKS pada materi termokimia siswa kelas XI IPA-3 SMA Negeri 6 Surakarta. Jurnal Pendidikan Kimia, 2(2), 85-91.

Florentina, N., \& Leonard. (2017). Pengaruh model pembelajaran kooperatif terhadap kemampuan berpikir kreatif matematis siswa. Formatif: Jurnal Ilmiah Pendidikan MIPA, 7(2), 96-106. http://dx.doi.org/10.30998/formatif.v7i2.1877

Huda, Miftahul. (2011). Pengajaran model-model dan pembelajaran. Jogjakarta: Pustaka Pelajar.

Kusnandar. (2009). Usaha Peningkatan Prestasi Belajar Matematika Dengan Mengefektifkan Metode Pemberian Tugas Pada Siswa, Skripsi. Universitas Muhammadiyah Surakarta.

Kahar, M. S. (2017). Pengembangan perangkat pembelajaran fisika dengan menggunakan model pembelajaran kooperatif tipe STAD. JIPF (Jurnal Ilmu Pendidikan Fisika), 2(2), 42-49.

Kahar, M. S. (2017). Analisis kemampuan berpikir matematis siswa SMA kota Sorong terhadap butir soal dengan graded response model. Tadris: Jurnal Keguruan dan Ilmu Tarbiyah, 2(1), 11-18.

Kemmis, S. \& Mc.Taggart, R. (1983). The Action Research Planner. 3rd ed. Victoria, Australia: Deakin University.

Khoiri, A., Nasihah, U., \& Kahar, M. S. (2017). Analisis prestasi belajar fisika berpendekatan SETS di tinjau dari motivasi berprestasi. Jurnal Riset dan Kajian Pendidikan Fisika, 4(2), 83-89.

Prihatini, E. (2017). Pengaruh metode pembelajaran dan minat belajar terhadap hasil belajar ipa. Formatif: Jurnal Ilmiah Pendidikan MIPA, 7(2), 171-179. http://dx.doi.org/10.30998/formatif.v7i2.1831 
Formatif: Jurnal Ilmiah Pendidikan MIPA

Vol. 8, No. 1, April 2018, pp. 43-50

p-ISSN: 2088-351X

e-ISSN: 2502-5457

DOI: http://dx.doi.org/10.30998/formatif.v8i1.2319 